\title{
MIGRATION AS A HUMAN RIGHT IN MEDIA REPORTING
} been written about migrants in Croatia, Serbia or Bosnia and Herzegovina professional accountability is expected from the media. The results of the research indicate that there are differences between the analyzed daily newspapers in the writing approach to migration issues as human rights. There are a few texts on the migrants' integration processes, and there are almost none of affirmative texts regarding the migration issues. Regardless of the country's official position on the Moroccan Agreement, the objective reporting on such a universal phenomenon should be implied. The level of problems accompanying migrants often goes towards the attitude of the society that is often and mainly formed through media discourse. Migration is today a human right, and this vulnerable population deserves a nondiscriminatory media attitude and response to it. The professionals should act and directly contribute with their activities to the full respect of all people, and at the same time, respect professional ethics including the topic of migration, asylum seekers, or refugees.

Key Words: migration as a human right, universal phenomenon, nondiscrimination, ethics

\section{Introductory considerations}

Economic problems and war risks, threats to the population security, and the overall political turbulence and strategic combinations, which have been inflicted on the countries such as Libya, Congo, Syria or Afghanistan, have caused mass migrations in recent years. The estimates of the UNHCR court are that there are, in the mobile states, several million refugees ${ }^{1}$, who try to find salvation from militant formations in the countries of the Western Europe, as well as their existence (Pavlović, 2017). The migration problem is multiple. There is also a difference in social responsiveness, depending on whether migration is talked about as a phenomenon or as a resulted consequence, in the countries of origin, transit or as a destination. An unbalanced and often negative pol-

\footnotetext{
* Zoran Pavlović, PhD, the Provincial Protector of Citizens - Ombudsman, Novi Sad, Republic of Serbia.

${ }^{1} \mathrm{https}: / /$ www.b92.net/info/vesti/index.php?yyyy=2018\&mm=06\&dd=19\&nav_category=78\&nav_id=1406760 visited on August $20^{\text {th }}, 2018$.
} 
icy towards the admission of migrants is a clear challenge that is posed not only at national, but also regional and international level. The risk factors for the victimization of the migrant population, as well as the correlation with the occurrence of human trafficking, the illicit crossing of the state border and human smuggling, etc., are numerous. Accepting the position of states and the international community's responsibility regarding the protection of human rights, dignity and migrants perspective, with preventive activities directed towards the reduction of violence against migrants, activities on the preparation of documents, whose implementation would significantly improve the existing situation, have been initiated. These documents have to be consistent with global goals, such as the UN sustainable development goals by 2030, which represent a universal call for action in order to eradicate poverty, protect the environment and ensure peace and pros${\text { perity for } \text { all. }^{2}}^{2}$

On this basis, one of the UN strategic documents developed in December 2018, titled the Global Migration Agreement and signed in Marrakesh, affirms the basic human rights of migrants, and it has been accepted by more than 160 countries. The agreement itself is a catalogue of various measures agreed upon by the states. There are the following five outlined goals: the access to a migrant crisis based on human rights, the protection of vulnerable migrants, the fight against xenophobia, racism and discrimination, the fight against illegal immigration and the assistance to returning migrants.

The document does not require ratification in the countries that have worked on it, with the possibility to decide what they would and would not like to use from the document. The difference between migrants and refugees has been made and it is stated that this is regulated by a special legal framework. At the same time, it has been emphasized that migrants are not only people fleeing from the war and other disasters. There are also economic migrants, people who go to other countries in order to work or for the purpose of education. The Declaration pays special attention to the labour and administrative protection of migrants.

It is envisaged that the educational programmes will be provided to children, who do not have the access to formal system, all the way to the training in the workplace. Finally, the health needs of migrants have been included in national and local health policies ${ }^{3}$.

The fact is that even during the media reporting on this Declaration, it has not been affirmatively written everywhere about the document whose only idea is the promotion and protection of basic human rights. What is fiction and what is reality in migrations becomes a very problematic issue. Fraudulent news or marketing content are often included in reporting on migrations. One thing is for sure - it is the media that plays an important role in creating an image of society and individuals about the migrants themselves and the competent institutions in the governmental and non-governmental sector. Without media coverage, migrant crises and migrations would remain unregistered for some groups of people and individuals, and the support would lack. This is why the public needs more accurate and verifiable information which, due to the role that the media has, contributes to building up the true picture of reality (Pavlović, 2018).

\footnotetext{
${ }^{2}$ http://www.rs.undp.org/content/serbia/sr/home/sustainable-development-goals.html visited on August 20 2018.

3 https://www.b92.net/info/vesti/index.php?yyyy=2018\&mm=12\&dd=10\&nav_category=78\&nav_id=1480090 visited on January $5^{\text {th }}, 2019$.
} 


\section{An example and a few questions}

At the end of 2018, the media in Serbia reported on a forty-year-old migrant, named Abdullah $^{4}$, who decided to continue his life here in Serbia. This event was covered in various sections, from chronicle to fun. Such reporting caused a series of positive and negative comments. The issue we have raised is the following: what the justified interest of the public is to know, what the information is, and also the implications for the migrant. Can one predict which information can be published in accordance with the Marrakesh Agreement? So far, the institutions responsible for protecting migrants' rights have not taken a stand on media writing and an attitude towards migrants and migration.

In Serbia, more than 30 migrants in 2018 received a work permit and were employed with the assistance of the Asylum Protection Center (APC), and Abdullah from Afghanistan, who has been living in Serbia for three years, is one of the 30 persons who received asylum last year. He opened an agency for the provision of translation services and thus became the first migrant entrepreneur. In order to start the translation business, with the support of the APC, and to assist refugees, asylum seekers and migrants, he was supposed to master the great way in order to get an ID card, be entitled to work/get his right to work, and receive asylum. He was even supposed to master the problem of opening a bank account.

In order that migrants in Serbia can get a work permit and be hired, it is necessary to apply for asylum, and they would get their right to work, that is, they would be entitled to work nine months from the beginning of the asylum procedure. In order to open a bank account they should have an ID card with a chip. An attempt has been made to answer some of these questions, according to the Marrakesh Agreement, by replacing a number of legal gaps, ambiguities and inaccuracies. Furthermore, in seeking these answers there should be public support, but the dilemma is whether it really exists, without prejudice, not only in Serbia, but also in the countries in the region. However, let's start searching for some answers.

\section{Methodological framework of the research}

The subject of this research is defined as the relationship of the media to migration and migration law, as well as to the Marrakesh Agreement in such context. Although, at first glance, it can only be dealt with the subject of international public and administrative law, the media discourse itself includes the inadequate response of the society to media reactions in relation to migrations and the consequences that it has in the countries of the region.

For the empirical research, a research technique for quantitative and qualitative content analysis has been selected. This method is one of the most common ones in social sciences with the model of structuring messages into general categories, so that they can be understood by more people. The results of the study of the analyzed text should show the presence or absence of certain characteristics, that is, their frequency and

\footnotetext{
${ }^{4}$ http://www.politika.rs/sr/clanak/423161/Abdulah-iz-Avganistana-prvi-migrant-preduzetnik-u-Srbiji visited on February $20^{\text {th }}, 2019$.
} 
variability (Weber, 2010; Neuendorf, 2002; Krippendorf, 1980). The initial assumption about migrations as a human right, depending on the nature of the media, has been that this issue is reported in an inappropriate way to some extent, and contrary to the current media and information regulations, professional codes, etc., also with often negative consequences for migrants and minimum human rights vested with them.

The topic of the concrete analysis has been the articles related to the adoption of the Marrakesh Global Agreement on Migrants. The texts were analyzed in the period from October $1^{\text {st }}$ to December $31^{\text {st }}, 2018$ published in the online editions of the following daily newspapers: Večernji list and Jutarnji list (Croatia); Blic and Večernje novosti (Serbia); Dnevni Avaz and Oslobodjenje (Bosnia and Herzegovina).

The above-mentioned analysis has included the following:

1. Number of articles

2. Type of articles (direct / indirect)

3. Sections in which articles are published

4. Themes

5. Final considerations

\section{Number of articles}

When collecting articles from the online editions of the listed daily newspapers, it has been noticed that in the given period, a total of 62 articles related to the Marrakesh Agreement were published.

Table 1 - Number of articles

\begin{tabular}{|l|c|}
\hline \multicolumn{1}{|c|}{ Daily newspapers } & Number of articles \\
\hline Večernji list (HR) & 17 \\
\hline Jutarnji list (HR) & 25 \\
\hline Blic (RS) & 4 \\
\hline Večernje novosti (RS) & 5 \\
\hline Dnevni avaz (B\&H) & 8 \\
\hline Oslobođenje (B\&H) & 3 \\
\hline Total & 62 \\
\hline
\end{tabular}

Out of the total number of articles, $68 \%$ were published in Croatian online editions of daily newspapers, $14 \%$ in Serbian and $18 \%$ in Bosnian and Herzegovinian. 


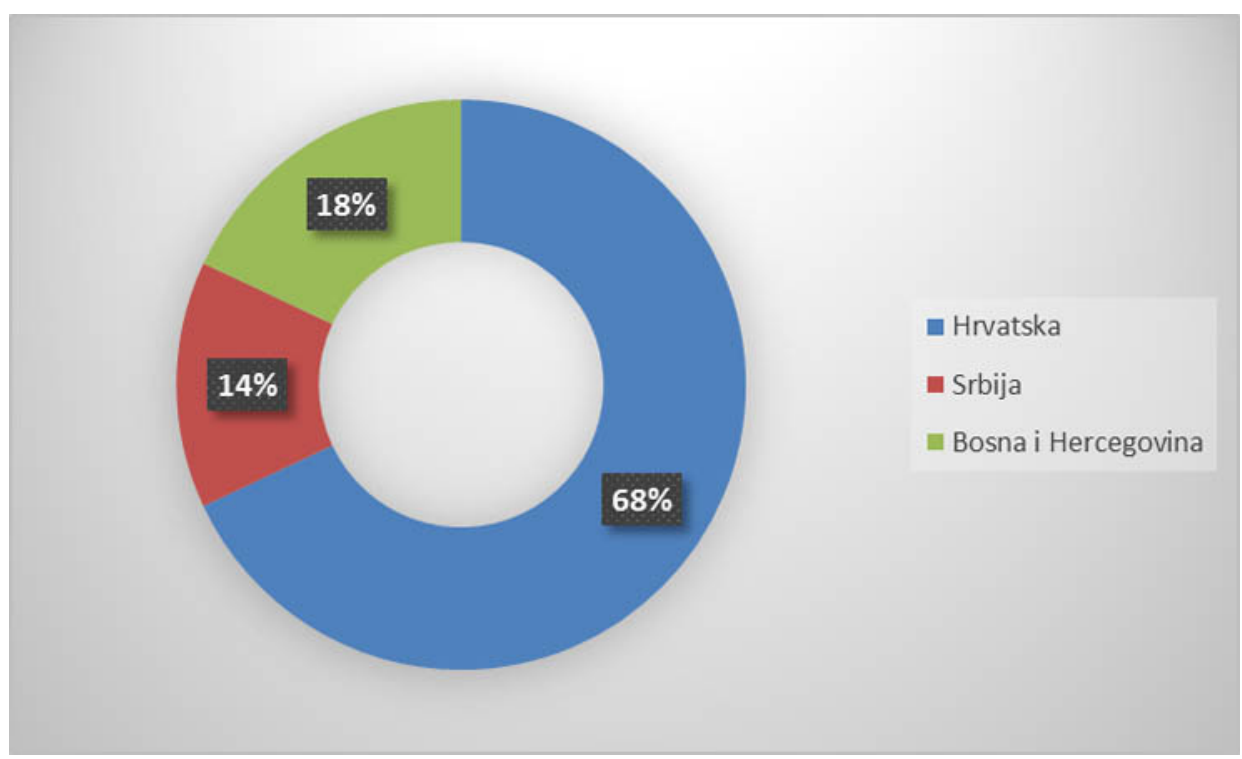

Chart 1 - Percentage of articles by country

When collecting the articles, it has been noticed that the greatest interest in this topic has been found in the Croatian daily newspapers that were the subject of observation. In the analyzed Serbian and Bosnian-Herzegovinian newspapers, there has been much less interest in writing and reporting on this topic. It can be concluded that for some reason the topic has not been attractive to them, as it is the case with the Croatian media.

\section{Types of articles and sections}

When it comes to the type of articles, or the representation of articles that address this topic directly or indirectly, the situation is the following:

- Večernji list: $65 \%$ direct, $35 \%$ indirect;

- Jutarnji list: $\mathbf{4 8 \%}$ direct, $\mathbf{5 2 \%}$ indirect;

- Blic: $100 \%$ indirect;

- Večernje novosti: $\mathbf{4 0 \%}$ direct, $60 \%$ indirect;

- Dnevni avaz: $25 \%$ direct, $\mathbf{7 5 \%}$ indirect;

- Oslobođenje: $33 \%$ direct, $67 \%$ indirect.

The obtained data indicate that the highest percentage of articles, which have been written directly on this topic, come out in the online editions of daily newspapers that are published in Croatia while in the observed online editions of daily newspapers published in Serbia, as well as Bosnia and Herzegovina, a significantly higher percentage of articles that approach the topic in an indirect way have been noticed, and often using it (the topic) as a supplement to the central topics of the articles. 
In continuation of the analysis of the articles dealing with Marrakesh Migrant Agreement, we have looked at the sections in which these articles have been published.

Table 2 - Heading/Sections

\begin{tabular}{|c|c|c|c|c|c|c|c|c|c|c|c|c|}
\hline \multirow{2}{*}{$\begin{array}{l}\text { Heading/ } \\
\text { Sections }\end{array}$} & \multicolumn{2}{|c|}{$\begin{array}{l}\text { Večernji list } \\
\text { (HR) }\end{array}$} & \multicolumn{2}{|c|}{$\begin{array}{l}\text { Jutarnji list } \\
\text { (HR) }\end{array}$} & \multicolumn{2}{|c|}{$\begin{array}{l}\text { Blic } \\
\text { (RS) }\end{array}$} & \multicolumn{2}{|c|}{$\begin{array}{l}\text { Večernje } \\
\text { novosti } \\
\text { (RS) }\end{array}$} & \multicolumn{2}{|c|}{$\begin{array}{c}\text { Dnevni avaz } \\
\text { (BiH) }\end{array}$} & \multicolumn{2}{|c|}{$\begin{array}{l}\text { Oslobođenje } \\
\text { (BiH) }\end{array}$} \\
\hline & $\begin{array}{l}\text { Num- } \\
\text { ber }\end{array}$ & $\%$ & $\begin{array}{l}\text { Num- } \\
\text { ber }\end{array}$ & $\%$ & $\begin{array}{l}\text { Num- } \\
\text { ber }\end{array}$ & $\%$ & $\begin{array}{l}\text { Num- } \\
\text { ber }\end{array}$ & $\%$ & $\begin{array}{l}\text { Num- } \\
\text { ber }\end{array}$ & $\%$ & $\begin{array}{l}\text { Num- } \\
\text { ber }\end{array}$ & $\%$ \\
\hline World & 3 & $18 \%$ & 11 & $44 \%$ & 4 & $100 \%$ & 0 & & 6 & $74 \%$ & 1 & $33 \%$ \\
\hline Croatia & 9 & $53 \%$ & 12 & $48 \%$ & & & & & 1 & $13 \%$ & & \\
\hline Columns & 4 & $24 \%$ & & & & & & & & & & \\
\hline Interviews & 1 & $6 \%$ & & & & & 2 & $40 \%$ & & & 1 & $33 \%$ \\
\hline Society & & & & & & & 3 & $60 \%$ & & & & \\
\hline Globe & & & 2 & $8 \%$ & & & & & & & & \\
\hline Region & & & & & & & & & & & 1 & $33 \%$ \\
\hline Zagreb & & & & & & & & & 1 & $13 \%$ & & \\
\hline
\end{tabular}

The sections in which the articles have been located are the following: world, Croatia, columns, interviews, society, globe, region and Zagreb. When we look at the daily newspapers in the countries where they come out, we see that the column dominating in the online editions of daily newspapers Vecernji and Jutarnji list is the section called Croatia. When it comes to daily newspapers Blic, the dominant section is the world; while the society is dominant in the daily newspaper Večernje novosti.

When it comes to daily newspapers from Bosnia and Herzegovina, we notice that most articles in Dnevni avaz are in the world section, while in the online edition of daily newspapers Oslobodjenje articles are evenly distributed in the sections of the world, the interviews and the region. 


\section{Topics of the articles}

Analyzing the contents of the articles, we have tried to sort them out based on subtopics, within the central processed topic.

Table 3 - Večernji list

\begin{tabular}{|c|c|c|c|c|c|c|c|c|}
\hline \multicolumn{9}{|c|}{ Topics of the articles } \\
\hline \multirow{2}{*}{$\begin{array}{l}\text { Večernji } \\
\text { list }\end{array}$} & \multicolumn{2}{|c|}{$\begin{array}{l}\text { Opposition to the } \\
\text { MarrakechAgreement }\end{array}$} & \multicolumn{2}{|c|}{$\begin{array}{c}\text { Who will attend } \\
\text { from the repre- } \\
\text { sentatives of the } \\
\text { Croatian govern- } \\
\text { ment? }\end{array}$} & \multicolumn{2}{|c|}{$\begin{array}{l}\text { Conference holding } \\
\text { and consequences of } \\
\text { the Marrakech } \\
\text { Agreement }\end{array}$} & \multicolumn{2}{|c|}{ Other } \\
\hline & 9 & $52 \%$ & 2 & $12 \%$ & 3 & $18 \%$ & 3 & $18 \%$ \\
\hline
\end{tabular}

In the online edition of daily newspapers Večernji list, three thematic units have been singled out.

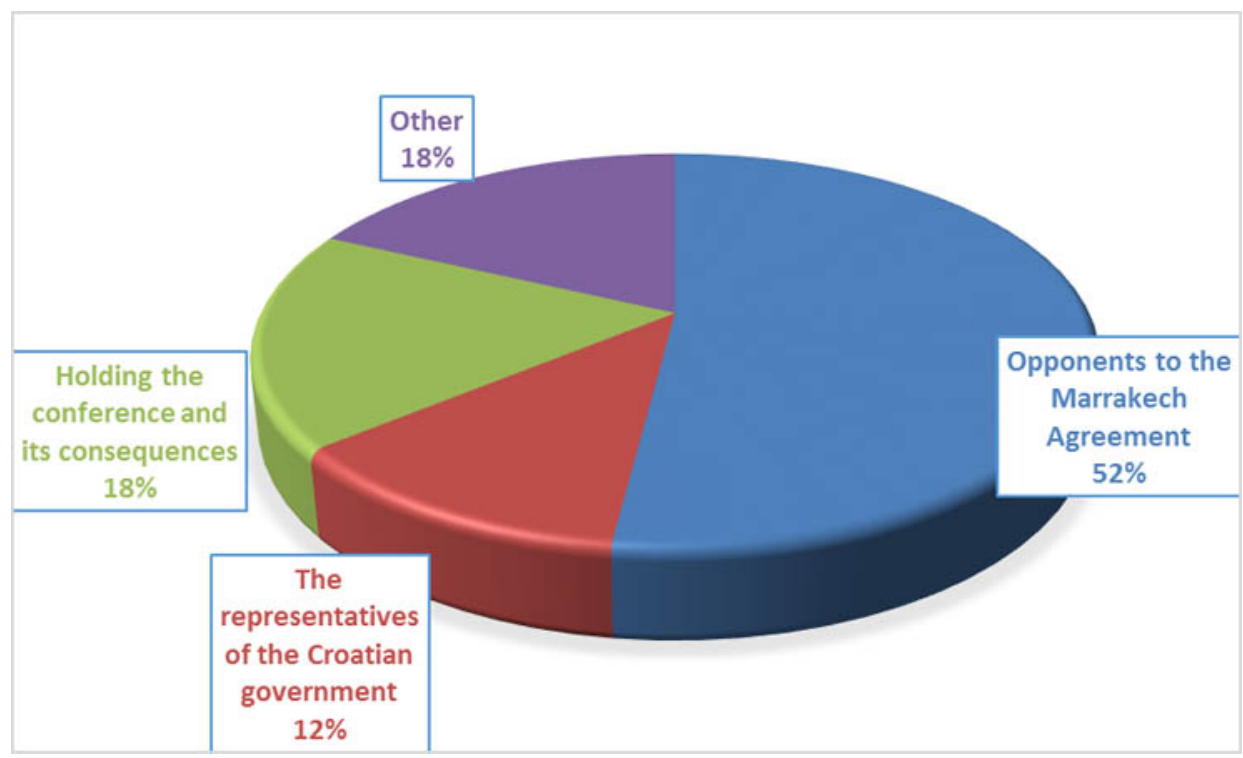

Chart 2 - Večernji list 
The majority of texts $(52 \%)$ are the texts that speak directly about the bad sides of the Marrakech Agreement and its opponents. We have come across the titles such as: The Marrakesh Agreement is the fraud of the UN; The Marrakesh Agreement is bad for Croatia; How is the Marrakech Agreement non-binding when it says "we commit" for 46 times? Some of these texts are an attempt to critically review this Agreement. However, some texts are openly opposed to this Agreement, and often the authors of the texts declare themselves as opponents of the Agreement. The texts represent the Agreement as a kind of fraud that is not sufficiently approached and explained to citizens. Also, two articles dealing with the participation of the representatives of the Croatian government in the conference have also been highlighted. They welcome the Croatian government decision that the participant is going to be the Minister of Internal Affairs, believing that thus Croatia has made it known to the world powers that the issue of migrants is its internal problem that it will deal with or address in its own way. The headlines of these articles are the following: Plenković: The government will determine who goes to Marrakesh; Prime Minister: Božinović will represent Croatia in Marrakech. As far as the texts from the third group are concerned, they are mainly related to reporting from the conference itself, the government representative clarifying what kind of significance and the consequences for Croatia and its policies towards migrants the conference has, but there can be found negative effects on the Croatian participation and support of the Agreement.

Table 4 - Jutarnji list

\section{Topics of the articles}

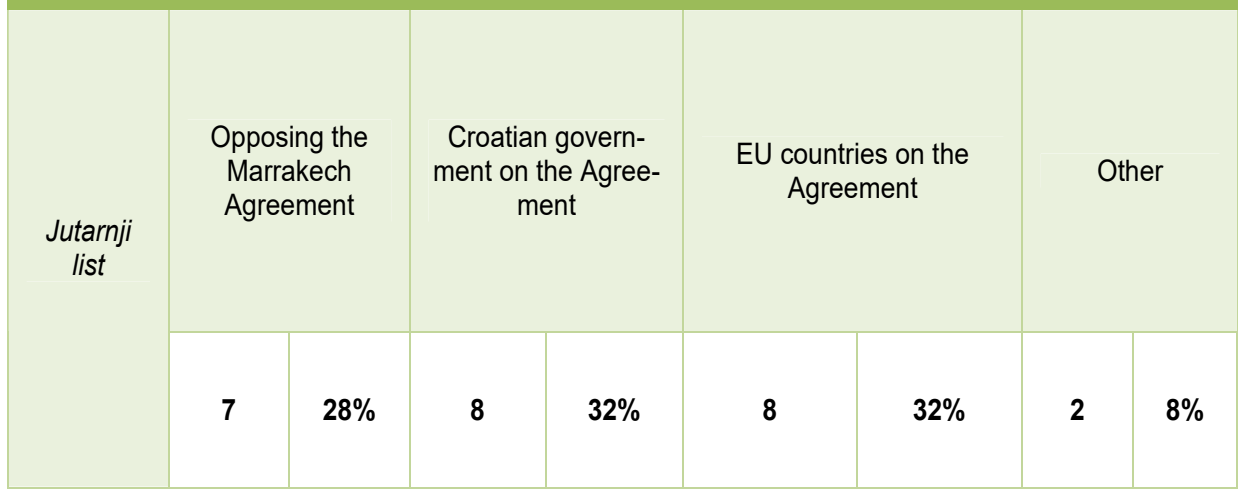

When it comes to the online edition of daily newspapers Jutarnji list, which has published the greatest number of articles during the observed period on this subject, we note that three thematic units have been re-separated: opposing the Marrakech Agreement, then the articles that represent statements and actions of the members of the Croatian government regarding the Agreement, and also the articles that convey the events and reactions from the European Union countries on this topic. The articles that represent the negative sides and the opposition to the Agreement constitute $28 \%$ of the texts published in the daily newspaper Jutarnji list on this topic. 


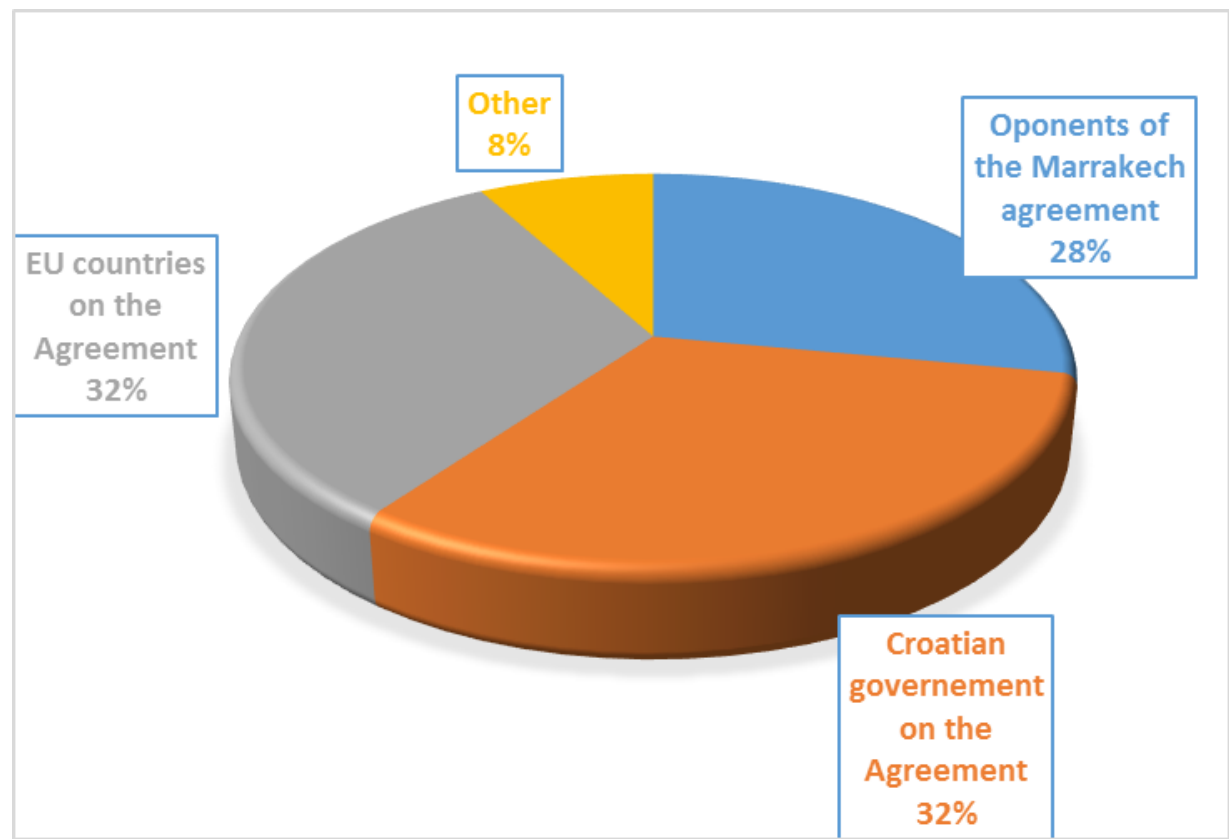

Chart 3 - Jutarnji list

These articles are the warning ones because they point to potential problems that might arise from the acceptance of the global migration agreement (Some of the titles: "Croatian Euro parliamenters warn about the radicalization of immigrants"; "The Marrakech Agreement has a disproportionate goal: to undermine the rule of law under the guise of human rights and introduce Sharia Law on Blasphemy"). The second group of texts (32\%), as we have already said, are the texts concerning the statements and views of the members of the Croatian state summit on this issue. These articles are in most cases related to conflicts and disagreements between the she-president and members of the government about who will go, and whether the representative of Croatia should go to the conference at all: "I agree that someone is trying to introduce strife between me and the government, but I do not know who. The President commented on rumors related to the Marrakesh Declaration"; "Plenković: Are there any attempts to disturb relations with the president or her advisers? Whoever is not with the Government, will not win elections."; "Plenković: Marrakech Agreement? The government did not change its position. Why has someone else changed the position, for example, the president, she must explain it to the public."The third group consists of the texts that broadcast events from the European countries on this issue. The articles are mainly dedicated to the events in Belgium, Slovenia and Hungary. They are mainly targeted at events in the countries that have refused or raised doubts in terms of supporting this Agreement: "The Marrakesh Agreement demolished the Belgian government. First the right-wingers left it, and then the Prime Minister resigned because the left-wing threatened him with mistrust." "Less support for the Marrakesh Agreement. Another member of the EU has rejected the UN Global Compact on Migration!"; 
"The Slovenian Parliament rejected the demand for a referendum on the Marrakesh Declaration. The Janez Janša initiative has failed."

At the beginning of the analysis, we have pointed out that in Serbian, as well as Bosnian-Herzegovinian media, much less has been reported and written on this subject. The online editions of daily newspapers Blic and Večernje novosti have a total of 9 articles, which mostly transmit reactions in Croatia and Slovenia.

Table 5 - Blic/Večernje novosti

\begin{tabular}{|c|c|c|c|c|c|c|}
\hline & \multicolumn{4}{|c|}{ Topics of the articles } & \multicolumn{2}{c|}{$\begin{array}{c}\text { Serbia supports the } \\
\text { Agreement }\end{array}$} \\
\hline Blic & \multicolumn{2}{|c|}{ Reactions in Croatia } & \multicolumn{2}{|c|}{ Reactions in Slovenia } & O & I \\
\hline $\begin{array}{c}\text { Večernje } \\
\text { novosti }\end{array}$ & $\mathbf{3}$ & $\mathbf{7 5 \%}$ & $\mathbf{2 5 \%}$ & $\mathbf{2 0 \%}$ & $\mathbf{2}$ & $\mathbf{4 0 \%}$ \\
\hline
\end{tabular}

The online edition of daily newspapers Blic has only 4 texts on this subject, 3 dedicated to the events and reactions in Croatia when it comes to the Marrakech Agreement. Two texts are dedicated to President Kolinda Grabar-Kitarović and her remarks on this Agreement: "The extreme right-wing is praising Kolinda:"She is a ruler close to the people that Germany nowadays can only dream about. "Kolinda got a hold of microphone during a grievous debate with a journalist." One text is dedicated to the protests against this Agreement that took place in Split: "Walking Against the Migrants", Split against the Marrakech Agreement, they carried a "SAY NO to THE VIOLENT ISLAMIZATION OF CROATIA" banner. One text is dedicated to the events in Slovenia and dilemmas about the acceptance of this Agreement: "Cerar: We will review the Marrakesh Agreement again."

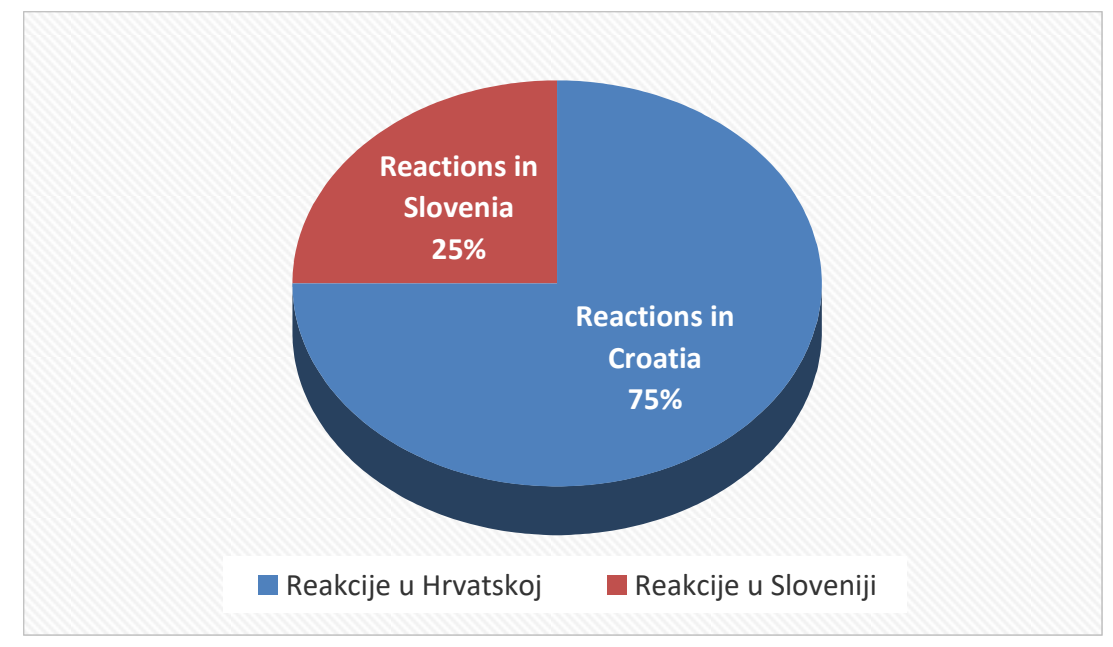

Chart $4-$ Blic 
The online edition of daily newspapers Vecernje novosti includes two texts dedicated to events in Croatia and Serbia. Both texts speak about developments in Croatia and convey a negative attitude towards migrants and the acceptance of a global agreement: "Croatia: 31 local TV stations temporarily remain without a concession due to the hate speech"; "The neighbors will not agree on the rights of migrants." It is interesting that the text on the loss of the concession for 31 local television stations from Croatia because they broadcast TV content filled with hate speech towards migrants, before the adoption of the Marrakech Agreement, has not been found in any of the two daily newspapers in Croatia, and also in the daily newspapers in B\&H. Both texts refer to Serbian position to support this Agreement: "Serbia supported the UN Declaration on Migrants." One text refers to the rejection of a referendum on this issue in Slovenia: "The Slovenian Parliament rejected a proposal for a referendum on the Marrakesh Agreement."

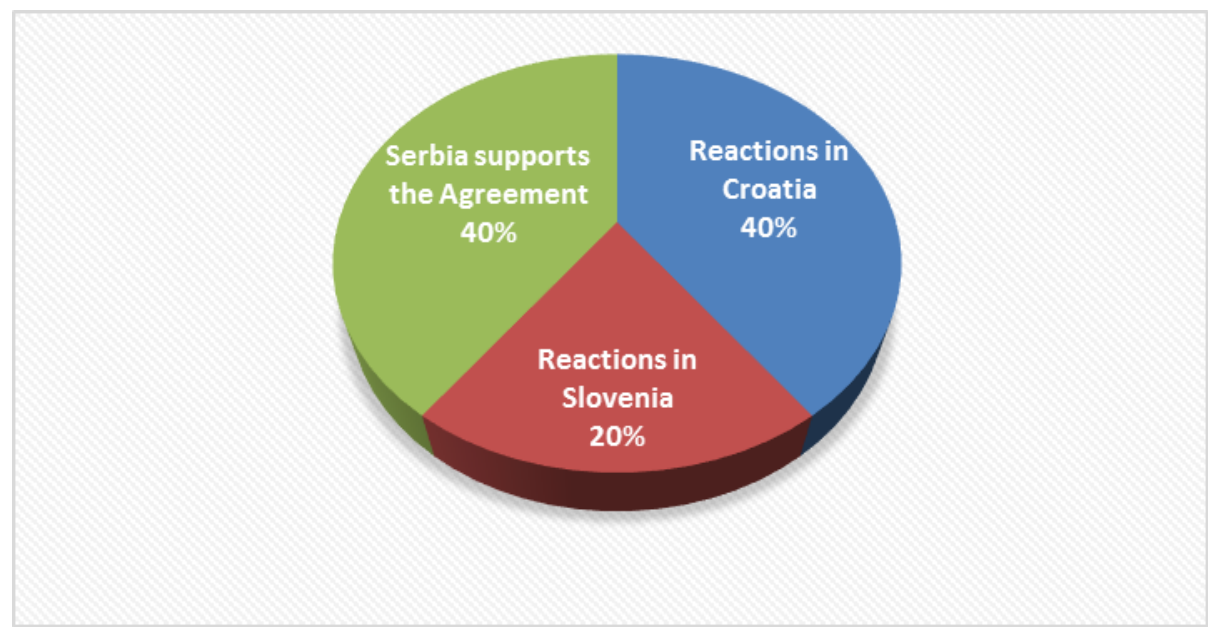

Chart 5 - Vecernje novosti

The analyzed online editions of daily newspapers that are published in Bosnia and Herzegovina also show less interest in reporting and writing on this topic. Only 11 texts have come out in both of them. The online edition of the daily newspapers Dnevni avaz has published 8 articles on the topic of the Marrakech Agreement.

Table 6 - Dnevni avaz/Oslobođenje

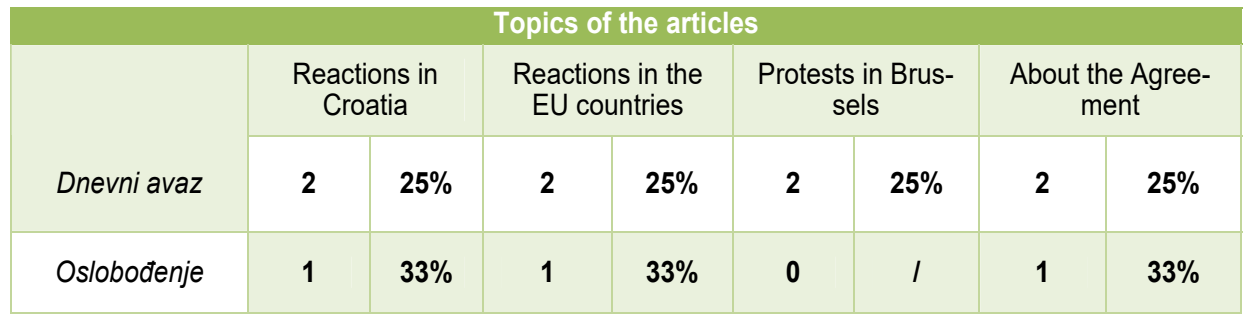




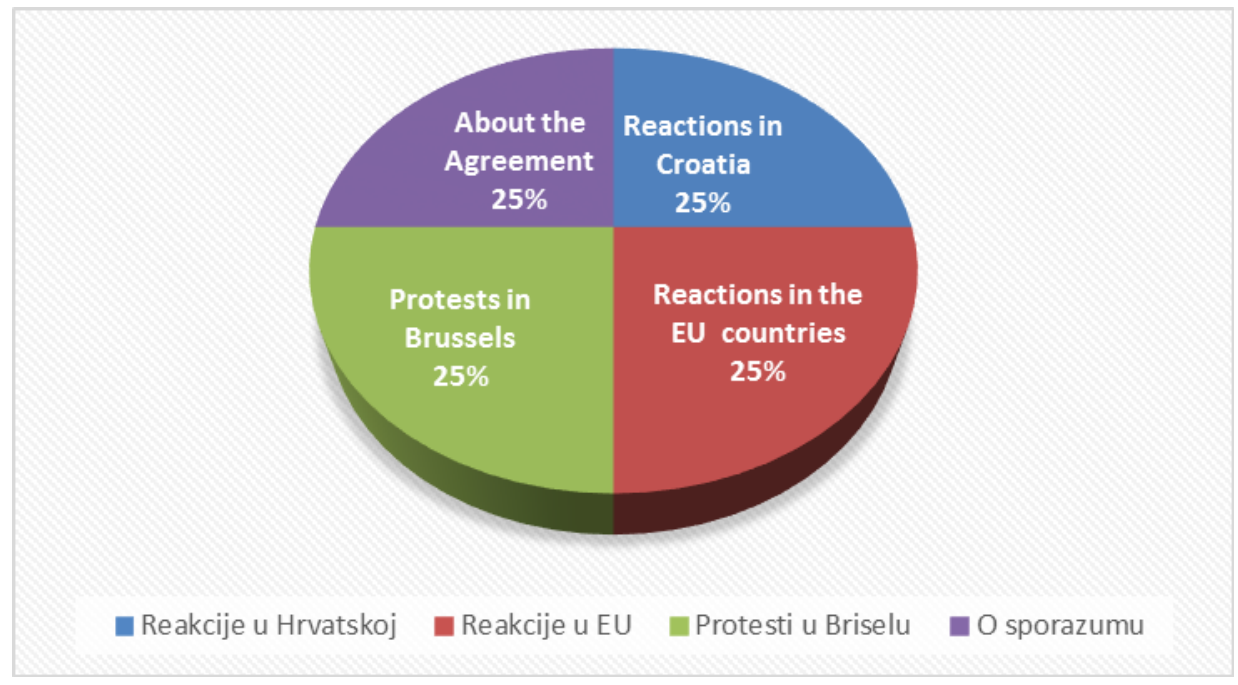

Chart 6 - Dnevni avaz

Two articles have been devoted to reactions in Croatia, one about President GrabarKitarović and her reaction to the issue related to this Agreement: "Grabar-Kitarović was upset by questions about migrants and took the microphone out of journalist's hand"; while the other generally deals with attitudes in Croatia on the subject of the Agreement. Two articles refer to the reaction to the Agreement in Belgium and Austria: "The Prime Minister of Belgium has resigned to King Philip."; "The following is an example of the United States and Hungary: Austria withdraws from the global agreement on migrants." Two articles are devoted to protests against agreements held in Brussels: "95 protesters have been arrested in Brussels against the Marrakech Agreement"; "Clashes at the protests, the police used water cannons." Both texts are informative. As the fourth thematic unit, two texts on the Agreement itself, informative ones, are set out: "The UN has accepted the Global Agreement on Refugees."; "The Marrakesh Agreement has been adopted by more than 160 countries."

The online edition of the daily newspapers Oslobodjenje has published 3 texts on this topic.

One text is concerned with the Agreement itself and presents an interview with Luis Arbur, a UN representative for migration. The text is affirmative in character, as the title itself suggests: "Building the human mobility of the 21st century." One text is devoted to the events in Slovakia and the withdrawal of their foreign minister's resignation, and in the context of his dissatisfaction with the fact that Slovakia has decided to reject the support of the Marrakesh Agreement. Also, an article is dedicated to the events in Croatia, namely protests against the support of the Agreement that took place in Split: "In Split Protests against the migrants: We will not have Arabs!" 


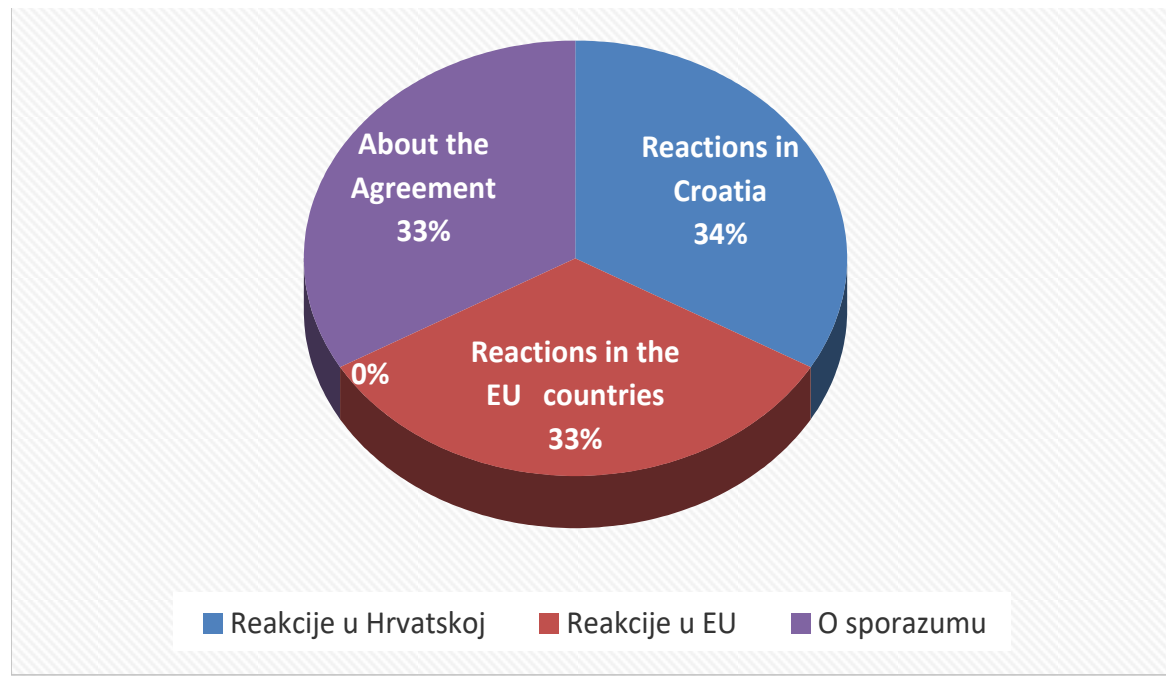

Chart 7 - Oslobodjenje

\section{Instead of the conclusion}

After collecting the articles and carrying out the comparative analysis of them in the previously mentioned online editions of the daily newspapers, we have come up with several conclusions. Certain differences in reporting and the lack in the reporting on the phenomenon of the migrant crisis and the possibilities for its mitigation exist in all three countries, whose media have been monitored. The interest in reporting on this topic is different from newspaper to newspaper, from country to country. There are a few texts on the integration of migrants, and almost none of affirmative texts. Regardless of the country's position on the Moroccan Agreement, the objective reporting on such a universal phenomenon should be implied. The level of problems accompanying migrants often leads to the attitude of the society that is often and largely formed through media discourse. Despite the widely agreed platform of the Agreement itself and the fact that it has been accepted by more than 160 countries, in some countries and power centers the Agreement has not come across reception. As the reason for opposing the Agreement, it is said that it will question the national sovereignty and lead to greater influx of migrants. Some answers will only be given to us by the future, and some, in concrete cases, are already visible now.

In this context, we could also set up a research hypothesis: how long it would take Abdullah to open an entrepreneurial agency in the other two countries, whose media has been analyzed; with or without the Marrakesh Declaration; and to give some recommendation regarding the protection of his rights, through the prism of the obligations and experiences that we have so far assumed, which we inherit from the past. But let's start orderly.

We have already noticed by counting and sorting the articles that there are some differences in the interest on this topic, depending on the country in which the observed daily newspapers come out. The online editions of daily newspapers that are published in Croatia show a significantly higher interest in writing on this subject than daily newspapers in Bosnia and Herzegovina 
and Serbia. Such a situation can be linked, in general, to the relations of these countries in regard to migrants and the Marrakesh Agreement. The impression is that the Marrakech Agreement is, for some reason, recognized in Croatia as "controversial", while in Serbia and Bosnia and Herzegovina it is viewed as something that does not need to be further examined.

The articles we have analyzed differ in the way they deal with the topic. The daily newspapers from Croatia, in most cases, approach the topic in a direct way, putting the Marrakech Agreement, as well as the dilemmas associated with it, as the central theme of articles, paying it the full attention. The daily newspapers in Serbia approach this topic in a more indirect way; articles are more dedicated to events in other countries, such as protests or disagreements of the governments of the European countries, which in fact have conflicting views on this Agreement.

The sections where the articles are mostly placed suggest a different approach to reporting on this subject. Most of the articles in the observed daily newspapers that are published in Croatia are located in the section called Croatia, while the daily newspapers that are published in Serbia, have classified their articles mainly in the sections called the world and society whereas the daily newspapers from Bosnia and Herzegovina dominate the world, region and interviews. Such findings match the previously observed and they again suggest that daily newspapers in Croatia have come to this phenomenon as an important internal issue, while newspapers from Serbia and B\&H have reported the Agreement as a global social phenomenon.

Having observed articles and their central themes, we have noticed that there is a significant percentage of texts in the Croatian daily newspapers (especially in Večernji list - 52\%) that are opposed to this Agreement and emphasize its negative sides, even the call for its rejection while newspapers in B\&H and Serbia mostly report only on the reactions to this Agreement in the region (Croatia and Slovenia), as well as other European countries (Belgium, Hungary, Slovakia, etc.), without calling for rejection or acceptance of the Agreement.

We conclude that in the media reporting the full respect for basic human rights of migrants is expected, without discrimination on any basis. Working on raising the expertise of such reporting could result in the higher quality in respecting the rights of those who are being written about, regardless of what is provided by the legally non-binding Marrakesh document.

\section{References}

[1] Pavlović, Z. (2017) Migration, refugees and sexual victimization, Balkan migration route: between politics of law and security, Proceedings, IMPP - PZGO, Belgrade, p. 213-228.

[2] Pavlović, Z., (2018) Media discourse on the migrant crisis and migrants, Proceedings of the Institute for Criminological and Sociological Research, Belgrade, p. 69-81.

[3] Neuendorf, K. (2002). The Content Analysis Guidebook. London: Sage.

[4] Krippendorf, K. (1980). Content analysis. An introduction to its methodology. Berverly Hills: Sage.

[5] Weber, R. P. (1990). Basic Content Analysis (2nd Edition). Newbury Park: Sage.

\section{Website References}

https://www.b92.net/info/vesti/index.php?yyyy=2018\&mm=06\&dd=19\&nav_category=78\&nav_id=14 06760 visited on August $20^{\text {th }}, 2018$.

http://www.rs.undp.org/content/serbia/sr/home/sustainable-development-goals.html visited on August $20^{\text {th }} 2018$.

https://www.b92.net/info/vesti/index.php?yyyy=2018\&mm=12\&dd=10\&nav_category=78\&nav_id=14 80090 visited on January $5^{\text {th }}, 2019$.

http://www.politika.rs/sr/clanak/423161/Abdulah-iz-Avganistana-prvi-migrant-preduzetnik-u-Srbiji visited on February $20^{\text {th }}, 2019$. 